\title{
Sudden Death Report in Mexico (1998-2014)
}

\section{Reporte de muerte súbita en Mexico (1998-2014)}

\author{
Angélica G. Fiscal-Málaga1, Heidi Sosa-Cruz'1,2, Ana L. Calderón-Garcidueñas ${ }^{1,3 *}$, Rubén Ruiz-Ramos ${ }^{1,3}$, \\ Noé López-Amador ${ }^{1}$, and Wendy Elena Becerra-Romero' \\ ${ }^{1}$ Instituto de Medicina Forense, Universidad Veracruzana, Boca del Río, Veracruz; ${ }^{2}$ Fiscalía General de Justicia del Estado de Sonora, Hermosillo, \\ Sonora; ${ }^{3}$ Faculty of Medicine, Universidad Veracruzana, Veracruz. Mexico
}

\begin{abstract}
Introduction: Sudden death $(S D)$ is a health problem worldwide affecting all strata of the population. The main cause of SD is ischemic heart disease (IHD). The aims of the study were as follows: (i) to analyze the incidence of deaths from IHD in two successive periods (1998-2006 and 2007-2015) to visualize the magnitude of the problem and (ii) to review the official reports of $S D$ in the same lapse of time. Materials and Methods: During that period, instantaneous death (ISD) and death that occurred in the first $24 \mathrm{~h}$ after the onset of symptoms were analyzed according to the official databases of National Institute of Statistics and Geography (INEGI) and National Health Information System (SINAIS). Results: There was an under-registration of SD cases in Mexico. Only 1394 cases of ISD were recorded officially in 17 years period of study, whereas it is estimated that 33,000 cases occur annually, exclusively due to sudden cardiac death. Conclusion: There is a serious gap in the official epidemiological information; placing the real problem in perspective would help to establish the adequate public policies for both, prevention and investigation of the causes of SD in Mexico.
\end{abstract}

Key words: Sudden death. Sudden cardiac death. 24 h sudden death. Mexico.

\section{Resumen}

Introducción: La muerte súbita (MS) es un problema mundial de salud que afecta a todos los estratos de la población. La principal causa de MS es la cardiopatía isquémica. Los objetivos del estudio fueron: i) Analizar la incidencia de muertes por cardiopatía isquémica en dos períodos sucesivos (1998-2006 y 2007-2015) para visualizar la magnitud del problema, y ii) revisar los informes oficiales de MS en los mismos lapsos. Metodología: Durante ese período, se analizaron la muerte instantánea (MSI) y la muerte ocurrida en las primeras $24 \mathrm{~h}$ después del inicio de los síntomas (MS24h) de acuerdo con las bases de datos oficiales del Instituto Nacional de Estadística y Geografía (INEGI) y el Sistema Nacional de Información de Salud (SINAIS). Resultados: Existe un subregistro de casos de MS en México. Solo 1,394 casos de MSI se registraron oficialmente en el período de estudio de 17 años, mientras que se estima que ocurren 33,000 casos al año, solo por muerte súbita cardíaca. Conclusión: Existe una subregistro de información epidemiológica oficial; poner el problema real en perspectiva ayudaría a establecer políticas públicas adecuadas tanto para la prevención como para la investigación de las causas de la MS en México.

Palabras clave: Muerte súbita. Muerte súbita cardíaca. Muerte súbita 24h. México.

Correspondence:

*Ana Laura Calderón Garcidueñas E-mail: acald911@ @otmail.com DOI: 10.24875/ACME.M19000038
Available online: $30-10-2019$ Arch Cardiol Mex (Eng). 2019;89(2):154-158 www.archivoscardiologia.com 2604-7063 @ 2018 Instituto Nacional de Cardiología Ignacio Chávez. Published by Permanyer México SA de CV. This is an open access article under the CC BY-NC-ND license (http://creativecommons.org/licenses/by-nc-nd/4.0/). 


\section{Introduction}

Sudden death (SD) has become a global health problem. It has a great public impact because it occurs unexpectedly, without apparent cause, and it may affect individuals of any age ${ }^{1}$.

In general, SD is divided into (1) instantaneous or fulminant SD (ISD), which occurs seconds or minutes or up to an hour after the collapse and in which the individual literally falls dead, usually in the presence of witnesses and generally associated with cardiac pathology including arrhythmias and (2) not instantaneous SD (24 h SD) that occurs up to $24 \mathrm{~h}$ after the onset of symptoms ${ }^{2}$.

$\mathrm{SD}$, in general, is responsible for 4-5 million annual deaths worldwide, the majority due to ischemic heart disease $(\mathrm{IHD})^{3}$.

Within the classification of ISD, sudden cardiac death (SCD) refers to death of cardiac origin that occurs within $1 \mathrm{~h}$ from the start of symptoms when death is witnessed.

In the United States of America, the SCD-adjusted rate by age and sex was $69 / 100,000$ inhabitants, with an estimate of 212,910 cases in $2009^{1}$. In Latin American countries, such as Cuba, the calculated rate for SCD was 90.9-101/100,000 inhabitants representing 11$12.3 \%$ of natural deaths ${ }^{4}$. In China, the rate was 41.3 cases/100,000 inhabitantsb/year ${ }^{5}$.

The most frequent causes of SCD include ischemic heart disease $(60-70 \%)$, cardiomyopathies $(20-30 \%)$, and primary arrhythmias $(5-10 \%)^{6}$.

In Mexico, the estimated annual incidence of acute myocardial infarction cases is around 140,000 , of which the fourth part dies in the event? ${ }^{7}$.

Some authors in Mexico, considering the number of deaths due to acute myocardial infarction, have calculated approximately 33-53,000 SCD/year ${ }^{8}$.

SD is not only a health problem, but by the fact of being unexpected, it may be suspicious of criminality. After discarding a criminal act, SD continues to have great importance, especially when it occurs in young people, because it is often necessary, in addition to a SD protocol of autopsy, a molecular autopsy to detect certain pathologies such as hereditary arrhythmogenic diseases or channelopathies ${ }^{9}$.

The aims of the study were as follows: (i) to analyze the incidence of deaths from ischemic heart disease in two successive periods (1998-2006 and 2007-2015) to visualize the magnitude of the problem and (ii) to review the official reports of SD in the same lapse of time and to compare these data with those calculated for annual SCD according to literature.

\section{Materials and methods}

It was a cross-sectional, descriptive, and retrospective study. The national epidemiological files of SD (ISD, $24 \mathrm{~h} \mathrm{SD}$ ) stored in the National Health Information System (SINAIS) ${ }^{10}$, and the information about the number of inhabitants in Mexico and main causes of death, at the files of the National Institute of Statistics and Geography (INEGI) ${ }^{11}$ were meticulously reviewed.

The cumulative incidence of deaths from ischemic heart disease in the periods of 1998-2006 and 2007$2015 / 10,000$ inhabitants was calculated in the global population and in those < 45 years of age. The same calculation stratified by sex was also performed. The population data for the first and second periods were obtained from the 2000 and 2010 population censuses, respectively ${ }^{11}$.

The information issued by SINAIS in relation to SD was analyzed and it was contrasted with the number of SCD calculated for Mexico according to literature.

\section{Results}

During the period of 1998-2006, there were 434,190 deaths from acute IHD in the country, with an incidence of 69.0 deaths $/ 10,000$ inhabitants in a population of 15 years or older; while in the population of $15-45$ years of age, there were 19,100 cases with an incidence of $4.1 / 10,000$ inhabitants (Table 1).

For the second period, the incidence increased, especially at the expense of mortality in men. This was remarkable even in young subjects because while the incidence of IHD in women between 15 and 45 years of age remained similar (1.6 and 1.7 for the first and second periods, respectively), in men, the increase was evident (Table 1).

The database with a record of SD in the general population in Mexico is the SINAIS. Two categories were found: ISD and $24 \mathrm{~h}$ sudden death ( $24 \mathrm{hSD}$ ). For 24 hSD, official record was found only from 1998 to 2005. As of the year 2006, this type of SD was no longer codified.

Table 2 shows the registered cases of ISD and 24 hSD at a national level in the general population $\geq$ 15 years of age according to SINAIS. In a period of 17 years, a total of 1394 cases of ISD were documented (an average of 82 cases/year). In the same period, in the group of $\leq 45$ years, only 319 cases were reported nationwide (19 deaths/year in average), of which 192 were men and 127 were women. ISD in $\leq 45$ years old was $22.8 \%$ of all cases. 
Table 1. Incidence of acute ischemic heart disease in Mexico

\begin{tabular}{|c|c|c|c|c|c|c|c|}
\hline \multicolumn{4}{|c|}{ Over 15 years of age (2000 census) } & \multicolumn{4}{|c|}{ Over 15 years of age (2010 census) } \\
\hline & $1998-2006$ & $\mathbf{W}$ & M & & 2007-2015 & W & M \\
\hline $\begin{array}{l}\text { Ischemic heart } \\
\text { disease }\end{array}$ & 434,190 & 193,994 & 241,007 & Ischemic heart disease & 645,241 & 283,648 & 361,540 \\
\hline 2000 census & ${ }^{*} 62,842,638$ & *32,798,814 & *30,043,824 & 2010 census & *78,423,336 & $* 40,766,755$ & *37,656,281 \\
\hline $\begin{array}{l}\text { Incidence per } \\
10,000 \text { inhabitants }\end{array}$ & 69.0 & 59.1 & 80.2 & $\begin{array}{l}\text { Incidence per } 10,000 \\
\text { inhabitants }\end{array}$ & 82.2 & 69.5 & 96.0 \\
\hline \multicolumn{4}{|c|}{$15-45$ years of age } & \multicolumn{4}{|c|}{$15-45$ years of age } \\
\hline $\begin{array}{l}\text { Ischemic heart } \\
\text { disease }\end{array}$ & 19,100 & 3948 & 15,152 & Ischemic heart disease & 27,424 & 4739 & 22,685 \\
\hline 2000 census & $45,904,906$ & $23,928,721$ & $21,976,185$ & 2010 census & $53,479,571$ & $27,599,180$ & $25,880,391$ \\
\hline $\begin{array}{l}\text { Incidence per } \\
10,000 \text { inhabitants }\end{array}$ & 4.1 & 1.6 & 6.8 & $\begin{array}{l}\text { Incidence per } 10,000 \\
\text { inhabitants }\end{array}$ & 5.1 & 1.7 & 8.7 \\
\hline
\end{tabular}

*Population from 15 to > 75 years old. W: women. M: men SOURCE: INEGI.

Table 2. Instantaneous SD and $24 \mathrm{~h}$ sudden death, 1998-2014 in Mexico

\begin{tabular}{|c|c|c|c|c|c|c|c|}
\hline ISD* & $\begin{array}{l}\text { 15-45 year old } \\
\text { cases }\end{array}$ & "UA cases & $\begin{array}{c}\text { All cases } \geq 15 \text { years } \\
\text { of age }\end{array}$ & 24 h SD* & $\begin{array}{l}15-45 \text { years old } \\
\text { cases }\end{array}$ & \#UA cases & $\begin{array}{l}15-45 \text { years old } \\
\text { cases }\end{array}$ \\
\hline 1998 & 27 & 1 & 78 & 1998 & 6 & 0 & 51 \\
\hline 1999 & 18 & 2 & 76 & 1999 & 6 & 2 & 34 \\
\hline 2000 & 17 & 0 & 80 & 2000 & 0 & 0 & 2 \\
\hline 2001 & 23 & 2 & 70 & 2001 & 5 & 0 & 13 \\
\hline 2002 & 21 & 1 & 97 & 2002 & 16 & 4 & 53 \\
\hline 2003 & 17 & 5 & 130 & 2003 & 2 & 1 & 9 \\
\hline 2004 & 27 & 0 & 126 & 2004 & 1 & 2 & 5 \\
\hline 2005 & 13 & 0 & 78 & 2005 & 2 & 0 & 8 \\
\hline 2006 & 12 & 2 & 49 & 2006 & NA & NA & NA \\
\hline 2007 & 26 & 0 & 77 & 2007 & NA & NA & NA \\
\hline 2008 & 17 & 1 & 70 & 2008 & NA & NA & NA \\
\hline 2009 & 20 & 0 & 84 & 2009 & NA & NA & NA \\
\hline 2010 & 17 & 0 & 87 & 2010 & NA & NA & NA \\
\hline 2011 & 12 & 1 & 79 & 2011 & NA & NA & NA \\
\hline 2012 & 20 & 1 & 88 & 2012 & NA & NA & NA \\
\hline 2013 & 18 & 0 & 66 & 2013 & NA & NA & NA \\
\hline 2014 & 14 & 0 & 59 & 2014 & NA & NA & NA \\
\hline TOTAL & 319 & 16 & 1394 & TOTAL & 38 & 9 & 175 \\
\hline
\end{tabular}

*SINAIS. ISD: instantaneous sudden death; <45 years old cases; UA: undetermined age. 24 hSD: $24 \mathrm{~h}$ sudden death that occurred $24 \mathrm{~h}$ or less after the onset of symptoms, SD: sudden death.

When the population between 15 and 45 years was analyzed in the same period of time, 8687 deaths in women and 37,837 deaths in men were attributed to acute myocardial infarction. If it is known that in ischemic heart disease, SD is the first form of presentation in $19-26 \%$ of patients ${ }^{12}$, then in the group of 15 to 
45 years old, calculating $20 \%$ of SD as the first manifestation of the disease, at least 9304 deaths (1737 women and 7567 men) could have presented as SD. This contrasts with the official report of 319 cases in total, for this same age group in the same lapse of time.

Table 2 shows also the number of $24 \mathrm{hSD}$ cases from 1998 to 2005; there were 175 cases with an average of 22 cases/year. In individuals $\leq 45$ years old, 38 cases were reported, 23 cases in men and 15 in women, with an annual average of five cases. All reports of 24 hSD were as mentioned, suspended without explanation since the year 2006.

\section{Discussion}

From the analysis carried out, it is evident that there is an under-registration of cases of SD in Mexico. The official figures are very low even when compared exclusively with the calculated SD of cardiac origin.

In the studied period of 17 years (1998-2014), only 1394 cases of ISD were registered, with an average of 82 cases/year. It is interesting to compare the official reports in Mexico with other countries. In Spain, in 1999, 9000 SD cases were calculated, with a population of around 40 million people at that time $(22.5 / 100,000 / \text { year })^{13}$. In China, in 2015, approximately 544,000 cases of SCD were reported in a population of 1376 million (39.5/100,000/year) ${ }^{14}$. In 2014, there was a report in Germany of SCD rate of 81/100,000/year ${ }^{15}$; in Ireland, in 2008, it was 55.5/100,000/year ${ }^{16}$, and in Thailand, in 1993, 38/100,000/year ${ }^{17}$.

As showed in Table 1, mortality from ischemic cardiovascular disease in Mexico is increasing, especially in men; however, one of its consequences, the SD has a very low official register. The poor record of these health problems can have a negative impact on the establishment of prevention measures at the public policy level since there is no official epidemiological support to show the reality of the problem.

Given that, the highest percentage of SD occurs in subjects $>45$ years old due to ischemic heart disease; it is advisable to control the risk factors such as atherosclerosis, obesity, diabetes mellitus, arterial hypertension, dyslipidemia, sedentary lifestyle, and smoking ${ }^{6}$. Furthermore, in the SCD in young people, it is necessary to implement preventive measures and detection of structural heart diseases and channelopathies ${ }^{18}$. Officially, $22.8 \%$ of all SD cases occurred in individuals between 15 and 45 years of age, and this is a worrisome situation. Preventive measures must be established, especially in high-performance athletes or in those children and young people in whom "innocent" clinical data (dyspnea, palpitations, and/or syncope) are not taken into consideration until it is done retrospectively after the SD of these subjects ${ }^{19}$.

Education of parents, teachers, coaches, and doctors is fundamental, as well as the participation of the government to control this health problem, in the Mexican population ${ }^{20}$.

\section{Conclusion}

The record of cases of SD in Mexico is far below the reality. Even so, $22.8 \%$ of SD cases occur in individuals 45 years of age or younger. From the framework of public policy, the implementation of preventive measures is urgent; besides, the education of the population is a priority.

\section{Conflicts of interest}

None.

\section{Funding sources}

This research did not receive any specific grant from funding agencies in the public, commercial, or not-forprofit sectors.

\section{Acknowledgments}

We are grateful for the scholarship granted by CONACYT for Master studies to AGFM and HSC. We appreciate the scholarship to support to the National System of Researchers, granted to WEBR.

\section{Ethical disclosures}

Protection of human and animal subjects. The authors declare that no experiments were performed on humans or animals for this study.

Confidentiality of data. The authors declare that no patient data appear in this article.

Right to privacy and informed consent. The authors declare that no patient data appear in this article.

\section{References}

1. Stecker EC, Reinier K, Marijon E, et al. Public health burden of sudden cardiac death in the United States. Circ Arrhythm Electrophysiol. 2014;7:212-7.

2. Chugh SS, Reinier K, Teodorescu C, et al. Epidemiology of sudden cardiac death: clinical and research implications. Prog Cardiovasc Dis. 2008;51:213-28. 
3. Bayes de Luna A, Elosua R. Muerte súbita. Rev Esp Cardiol. 2012;65:1039-52.

4. Ochoa-Montes LA, Tamayo-Vicente ND, González-Lugo M, et al. Resultados del grupo de investigación en muerte súbita, 20 años después de su creación. Rev Cubana Salud Pública. 2015;41:298-323. Available from: http://www.scielo.sld.cu/scielo.php?script=sci_arttext\&pi$d=S 0864-34662015000200010 \&$ Ing=es. [Last accessed on 2018 Jul 08].

5. Hua W, Zhang LF, Wu YF, et al. Incidence of sudden cardiac death in China: analysis of 4 regional populations. J Am Coll Cardiol. 2009;54:1110-8

6. Rodríguez-Reyes $\mathrm{H}$, Muñoz Gutiérrez M, Márquez MF, et al. Sudden cardiac death. Risk stratification, prevention and treatment. Arch Cardiol Mex. 2015;85:329-36.

7. Chávez Domínguez R, Ramírez Hernández JA, Casanova Garcés JM Coronary heart disease in Mexico and the clinical epidemiological and preventive relevance. Arch Cardiol Mex. 2003;73:105-14

8. Asensio E, Narváez R, Dorantes J, et al. Conceptos actuales sobre la muerte súbita. Gac Méd Méx. 2005:141:89-98.

9. Campuzano O, Beltramo P, Fernandez A, et al. Molecular autopsy in a cohort of infants died suddenly at rest. Forensic Sci Int Genet. 2018 37:54-63

10. Sistema Nacional de Información en Salud. Available from: http://www. dgis.salud.gob.mx/contenidos/sinais/e_mortalidadgeneral.html. [Last accessed on 2018 Aug 09].
11. Instituto Nacional de Estadística y Geografía Available from: http://www. beta.inegi.org.mx/proyectos/ccpv/2000. [Last accessed on 2018 Aug 09].

12. Kuller L, Lilienfeld A, Fisher R. Epidemiological study of sudden and unexpected deaths due to arteriosclerotic heart disease. Circulation. 1966;34:1056-68.

13. Instituto Nacional de Estadística de España. Available from: http://www. ne.es/censo2001/historia.htm. [Last accessed on 2018 Aug 10].

14. Zhang S. Sudden cardiac death in China: current status and future perspectives. Europace. 2015;17 Suppl 2:214-8

15. Martens E, Sinner MF, Siebermair J, et al. Incidence of sudden cardiac death in Germany: results from an emergency medical service registry in lower saxony. Europace. 2014;16:1752-8.

16. Byrne R, Constant $O$, Smyth $Y$, et al. Multiple source surveillance incidence and aetiology of out-of-hospital sudden cardiac death in a rural population in the West of Ireland. Eur Heart J. 2008;29:1418-23.

17. Tungsanga K, Sriboonlue P. Sudden unexplained death syndrome in North-East Thailand. Int J Epidemiol. 1993;22:81-7.

18. Garcia-Elias A, Benito B. Ion channel disorders and sudden cardiac death. Int J Mol Sci. 2018;19:E692.

19. Marrakchi S, Kammoun I, Bennour E, et al. Inherited primary arrhythmia disorders: cardiac channelopathies and sports activity. Herz. 2018. Doi: 10.1007/s00059-018-4706-2

20. Twig $\mathrm{G}$, Yaniv $\mathrm{G}$, Levine $\mathrm{H}$, et al. Body-mass index in 2.3 million adolescents and cardiovascular death in adulthood. N Engl J Med. 2016;374:2430-40. 